\title{
Rekonstruksi Paradigma Filsafat Ilmu: Studi Kritis Terhadap Ilmu Hukum Sebagai Ilmu
}

\author{
Safrin Salam $1 *$ \\ ${ }^{1}$ Jurusan Hukum Perdata, UNISMUH Buton. Jl. Betoambari, Kota Bau-Bau, Indonesia. \\ * Korespondensi Penulis. E-mail: salamsafrin2@gmail.com, Telp: 085341621268
}

\begin{abstract}
Abstrak
Filsafat ilmu mengemukakan alasan yang mendasar mengapa pengetahuan diperlukan bagi keteraturan dalam hidup manusia. Dalam hubungannnya dengan antara filsafat ilmu dan ilmu hukum sangat berhubungan erat. Tujuan penelitian ini adalah a) untuk menganalisis, menjelaskan dan memahami paradigma filsafat ilmu terhadap eksistensi ilmu hukum dan b) untuk menganalisis, menjelaskan dan memahami hakekat tujuan dari pembentukan ilmu hukum sebagai ilmu. Jenis penelitian yang digunakan penelitian ini adalah penelitian hukum normatif dengan menggunakan sumber bahan hukum berupa bahan hukum primer dan hukum sekunder. Hasil penelitian menunjukan bahwa pada Aspek Ontologi obyek kajian dalam ilmu hukum adalah norma-norma, seperti, norma perilaku dan norma kewenangan, termasuk norma-norma yang telah hidup secara turun temurun dalam masyarakat, aspek epistemologi adalah ilmu hukum menghimpun, menginterpretasi, memaparkan dan mensistematisasi bahan hukum yang terdiri aas asas-asas, aturan-aturan dan putusan-putusan hukum suatu tatatanan hukum untuk menghadirkannya sebagai suatu sistem dan dari aspek Aksiologi ilmu hukum dalam pengembangannya memiliki manfaat berupa penyelesaian terhadap semua masalah hukum konkret (problem solving) yang terjadi dalam masyarakat sedangkan hakekat dari Tujuan Pembentukan Ilmu Hukum Sebagai Ilmu dapat ditelaah dari hakekat dari lahirnya ilmu itu sendiri yakni kehadirannya untuk mencari kebenaran. Kebenaran dalam Ilmu hukum dihubungkan dengan Teori-Teori Kebenaran sejatinya ilmu hukum mencari kebenaran pragmatis yang mana keberadaannya sebagai ilmu untuk membawa manfaat (kedamaian) di tengah-tengah kehidupan masyarakat.
\end{abstract}

Kata Kunci: filsafat ilmu, ilmu hukum, ilmu

\section{Reconstruction of the Philosophy of Paradigm of Science: Critical Study of Law as a Science}

\begin{abstract}
The philosophy of science presents a fundamental reason why knowledge is necessary for regularity in human life. In its relationship with the philosophy of science and legal sciences is very closely related. The purpose of this research is a) to analyze, explain and understand the philosophy of the scientific paradigm to the existence of legal sciences and $b$ ) to analyze, explain and understand the nature of the purpose of the establishment of legal sciences as a science. This type of research used in research is normative legal research using the source of legal material in the form of primary legal material and secondary law. The results showed that on the ontology aspect of the study object in the legal sciences are the norms, such as the norms of behavior and norms of authority, including the norms that have lived hereditary in society, the epistemological aspect is the science The law of collecting, interpreting, exposing and systematizing the legal material consisting of the principles, rules and ruling decisions of the law to present it as a system and from the axiology of the legal sciences in Its development has benefits in the form of solutions to all the problems of concrete law (problem solving) that occur in the society while the nature of the purpose of forming the law as science can be studied from the essence of the birth of the science Own His presence to seek truth. Truth in the science of law is attributed to the theories of truth in the law of science seeking pragmatic truths which are the science to bring benefits (peace) in the midst of community life.
\end{abstract}

Keywords: philosophy of science, legal sciences, science 


\section{PENDAHULUAN}

Hakekat keberadaan manusia tidak dapat dilepaskan dengan peran kelahiran manusia sebagai Makhluk manusia itu sendiri dan manusia sebagai makhluk ciptaan Allah SWT. Sebagai Makhluk Allah SWT. Allah telah menciptakan manusia dengan segala kemampuan hebatnya baik secara jasmani, rohani dan kemampuan berpikirnya yang memmbuatnya berbeda dengan makhluk Allah lainnya. Sebagaimana firman Allah SWT pada Q.S. Al Baqarah ayat 242, Allah Berfirman dalam QS Aal Ankabut: 43:

"Demikianlah Allah menerangkan kepadamu ayat-ayatNya supaya kamu memahaminya. Dan perumpamaan-perumpamaan ini kami buatkan untuk manusia, dan tiada yang memahaminya kecuali orang-orang berilmu".

Kemudian dipertegaspula pada surah Alquran lainnya, manusia sebagai makhluk sempurna. (Q.S. at Tin ayat 4) dan merupakan satu-satunya makhluk yang pertama kali mengggunakan bahasa. (Q.S. Al Baqarah ayat 304-34).

Olehkarena manusia oleh Allah swt telah dimuliakan kedudukan eksistensinya maka dapat dimaknah bahwa setidaknya manusia memiliki tiga keistimewaan dibandingkan makhlun lain, yaitu: penguasaan bahasa, kemampuan berpikir, dan kesempurnaan bentuk ragawi. ${ }^{1}$ Dengan keistimewaan itu maka manusia mendapatkan pengetahuan berdasarkan kemampuannya selaku makhluk yang berpikir, merasa dan mengindera. Di samping itu manusia bisa juga mendapatkan pengetahuannya lewat instituisi dan wahyu dari Tugan yan disampaikan lewat utusan-Nya. ${ }^{2}$

Olehkarena ilmu pengetahuan merupakan formulasi pengetahuan manusia tentang alam semesta yang disajikan lewat rumusan yang sistematik dan rasional. Keberadaan Manusia dan ilmu pengetahuan merupakan perwujudan bersama-sama kehidupannya, hal ini didsasari olehkarena rasa ingin tahu manusia terhadap segala sesuatu di alam semesta ini. Weber mengemukakan bahwa:

"For Weber, science as a vocation meant more than science as a career choice. He saw science as a calling, fully in the sense that one speaks of a religious vocation-a lifelong dedication, a total commitment. His concern was to contrast this vocation with others, the vocations of the politician, of the artist, of the religious believer. The first essential distinction is that scientific work is unique in being always subject to change, to being superseded". ${ }^{3}$

Bagi Weber, ilmu pengetahuan merupakan panggilan berarti lebih dari sekadar sains sebagai Pilihan karir. Weber melihat bahwa ilmu pengetahuan sebagai panggilan, sepenuhnya dari illahi dalam arti bahwa seseorang berbicara tentang panggilan keagamaan - dedikasi seumur hidup, komitmen mutlak. Keprihatinannya untuk membedakan panggilan ini dengan orang lain, panggilan dari politikus, seniman. Keingintahuan manusia yang tercermin dalam ilmu pengetahuan tercermin dalam perkembangan ilmu pengetahuan. Augoste comte misalnya mengklasifikasikan tiga tahapan perkembangan kebudayaan (termasuk keilmuan) pada umumnya, yaitu tahapan a) theologies (b) metafisik dan (c) positivistik. Tahapan theologies ditandai dominasi kekuatan adikodrati atas diri manusia, sehingga peran subyek tenggelam dalam kekuatan alam atau Tugan. Metafisik ditandai adanya kemajuan dalam diri manusia sebagai subyek. Disini manusia sudah memperoalkan tentang keberadaan dirinya, namun belum mampu merealisasikan kekuatan dirinya secara maksimal bagi kebutuhan konkritnya. Terakhir adalah Positivistik, ditandai adanya sikap ilmiah dengan segala ukuran yang jelas dan pasti, sehingga bisa dipertanggungjawabkan keasiliannya. ${ }^{4}$

Pada tahapan yang terakhir yakni tahapan positivistik atau fungsional yang mencirikan adanya karakteristik yang sedikit banyak akan banyak mempengerahi wajah ilmu pengetahuan hingga saat ini. Ilmu pengetahuan yang dicirikan adanya kemampuan manusia untuk memanfaatkan kekuatan dalam bagi kepentingannya yang di dalamnya terkandung adanya sikap ilmiah yang lebih jelas dengan segala ukuran yang jelas dan dapat dipertanggungjawabkan secara ilmiah. Di sinilah kemudian muncul

${ }^{1}$ Inayatur Rosyidah, "Relevansi Ilmu Pengetahuan, Filsafat, Logika Dan Bahasa Dalam Membentuk Peradaban," El Harakah 12, no. 1 (2010): 19.

2 Rosyidah.

${ }^{3}$ H F Judson, "The Difficult Interface: Relations between the Sciences and the Law," PERSPECTIVES ON PROPERTIES OF THE HUMAN GENOME PROJECT 50 (2003): 483-505.

${ }^{4}$ Paulus Hadisuprapto, "Ilmu Hukum (Pendekatan Kajiannya)," Inovatif: Jurnal Ilmu Hukum 2, no. 4 (2010). 
pengertian ilmu pengetahuan sebagai suatu pengetahaun yang memiliki obyek, metode dan sistematika tertentu dan bersifat universal. Dengan demikian, bahwa ilmu pengetahuan berkembang searah dengan perkembangan kebudayaan manusia, dan ia berkembang dalam kerangka keingintahuan manusia untuk menemukan kebenaran. Dengan kata lain, ilmu pengettahuan lahir dari dorongan keingintahuan manusia dalam kerangka mencari kebenaran. ${ }^{5}$ Diakui bahwa upaya pencarian kebenaran dalam kerangka kehidupan manusia tidak lewat ilmu pengetahuan tetapi dengan cara lain yang secara actual tidak dapat dibantah kebenarannya yaitu Wahyu dan Institusi. Dua perolehan kebenaran manusia lewat wahyu dan instuisi telah terbukti kebenarannya dalam pengalaman hidup manusia di dunia ini.

Pada hubungannya dengan perkembangan Ilmu dalam konteks filsafat ilmu, Menurut Koento Wibisono Siswomihardjo menyatakan bahwa obyek filsafat ilmu adalah tiang-tiangnya penyangga eksistensi ilmu pengetahuan, yaitu Ontologi, Epistemologi dan Aksiologi. Ontologi adalah salah satu cabang filsafat membahas apa hakikat (being qua being) itu. ${ }^{6}$ Idealisme atau spiritualisme, materialism, dualism, pluralism, dan sebagainya merupakan faham dalam Filsafat Ontologi. Epistemologi sebagai cabang filsafat membahas apa sarana dan bagaimana tatacara untuk mencapai pengetahuan, dan bagaimana ukuran bagi apa yang disebut kebenaran atau kenyataan ilmiah itu. Aksiologi sebagai salah satu cabang filsafat yang membahas nilai (value) sebagai imperative dalam penerapan ilmu pengetahuan secara praktis. ${ }^{7}$

Relevansi keberadaan filsafat ilmu hubungannya dengan eksistensi ilmu hukum bahwasanya dalam komunitas yang senantiasa penuh dengan dinamika itu kemudian terjadilah proses interaksi sosial, sehingga dari aspek sosial tersebut melahirkan hukum yang nantinya turut berperan dalam menentukan, membentuk, dan mengendalikan masyarakat (law as a tool of social-engineering). Hukum yang dibentuk oleh aspek sosial tersebut memperoleh legitimasi (pengakuan) dari masyarakatnya, baik berupa legitimasi (pengakuan) dari masyarkatnya, baik berupa legitimasi yuridis (hukum) maupun legitimasi politis. Dengan berbekal legitimasi itulah akhirnya penguasa dapat menerapkan hukum yang pada awalnya muncul dari masyarakat untuk menjadi instrument kebijakannya terhadap masyarakat. Dengan situasi dan konsisi kemudian melahirkan Ilmu Hukum. Menurut J.H. Von Kirchman menyatakan bahwa dalam essensinya ilmu hukum adalah bukan ilmu hukum, karena obyek studi dari ilmu hukum adalah hukum positif yang hidup dalam masyarakat. Sistem hukum positif senantiasa mengalami perubahan sesuai dengan perubahan kebutuhan hukum masyarakat. ${ }^{8}$ Namun menurut Bernard Arief Sidharta bahwa status keilmuan hukum tidak perlu diragukan lagi, karena semua ciri ilmu telah dipenuhi oleh ilmu hukum. ${ }^{9}$

Perdebatan para ahli tentang ilmu hukum sebagai ilmu dalam konteks globalisasi hari ini harus diletakkan pada dimana hukum itu hadir yakni dimulai dari sebuah gejala ialah gejala hukum (hidup dan penghidupan hukum). Hukum tersebut merupakan sesuatu yang berkenaan dengan manusia, hukum tidak aka nada bila tidak ada manusia. Olehkarena adanya hubungan antara manusia dengan hukum maka pada paradigm filsafat maka perlu ditelaah terlebih dahulu salah satu aspek dari manusia yang berkaitan erat dengan hukum ialah perilakunya. Melalui filsafat perilaku atau etika. Dengan demikian filsafat manusia ialah pohonnya, salah satu cabangnya ialah filsafat etika, dan salah satu cabang dari filsafat etika ialah filsafat hukum, yang sekaligus sebagai ranting pohon filsafat manusia. Filsafat manusia sering disebut "genus" filsafat, filsafat etika merupakan "species-nya", dan filsafat hukum sebagai "sub-species-nya". Olehakrena itu terdapat hukubangan yang organik antara manusia, hukum yang berakar pada filsafat hukum sebagai sub-speciesnya yang mana salah satu objek kajian dari filsafat hukum adalah ilmu hukum itu sendiri. Berdasarkan penjelasan dan perdebatan ahli i tentang eksistensi ilmu hukum sebagai ilmu dan bukan ilmu menjadi menarik untuk dikaji ilmu hukum dalam paradigma filsafat ilmu secara teoritik dan prakteknya di Indonesia.

\title{
METODE
}

\author{
${ }^{5}$ Hadisuprapto. \\ ${ }^{6}$ Hadisuprapto. \\ ${ }^{7}$ Hadisuprapto. \\ ${ }^{8}$ B Arief Sidharta, Apakah Hukum Itu (Bandung: Universitas Katolik Parahyangan, 2000). \\ ${ }^{9}$ Arief Sidharta.
}


Penelitian ini menggunakan jenis penelitian hukum normatif (normative legal research). Pendekatan penelitian yang digunakan dalam penelitian ini ada 2 (dua) yaitu pendekatan undangundang (statute approach), pendekatan konseptual (conceptual approach).$^{10}$

Untuk memecahkan isu hukum penelitian yang diangkat oleh peneliti, diperlukan sumbersumber penelitian yakni bahan hukum primer, bahan hukum sekunder. Bahan hukum primer merupakan bahan hukum yang bersifat autoritatif artinya mempunyai otoritas. Bahan-bahan hukum primer terdiri dari perundang-undangan, catatan-catatan resmi atau risalah dalam pembuatan perundang-undangan dan putusan-putusan hakim. Sedangkan bahan-bahan sekunder berupa semua publikasi tentang hukum yang bukan merupakan dokumen-dokumen resmi. Pubikasi tentang hukum meliputi buku-buku teks, kamus-kamus hukum, jurnal-jurnal hukum, dan komentar-komentar atas putusan pengadilan. ${ }^{11}$

Bahan-bahan hukum yang diperoleh peneliti kemudian diteliti menggunakan pendekatan yang ada yaitu Pendekan perundang-undangan dan pendekatan konsep untuk menjawa isu hukum yang kemudian peneliti akan memberikan preskripsi tentang legal solution (solusi hukum) atas isu hukum yang dibahas.

\section{HASIL DAN PEMBAHASAN}

\section{A. Paradigma Filsafat Ilmu terhadap Eksistensi Ilmu Hukum}

Filsafat merupakan terjemahan dari istilah "philosophia", yang berasal dari dari bahasa Yunani dan berarti cinta akan kebijaksanaan "love of wisdom" (Philo artinya cinta, dan Sophia artinya kebijaksanaan). Dalam bahasa lain, filsafat dikenal dengan sebutan philosophy (Inggris), sedangkan orangnya disebut filsuf/filsof/philosophus yang artinya "pecinta kebijaksanaan".

Bijaksana memiliki dua segi arti, yang pertama memiliki pengertian yang mendalam dan yang kedua memiliki sikap hidup yang benar. Sementara benar adalah yang baik dan yang tepat. Jadi filsafat itu mencari kebijaksanaan. Dalam cakrawala lain, Sophia diartikan lebih luas lagi daripada kebijaksanaan diantaranya: 1) kerajinan; 2) kebenaran pertama; 3) pengetahuan yang luas; 4) kebijakan intelektual; 5) pertimbangan yang sehat; 6) kecerdikan dalam memutuskan hal-hal praktis. Sedangkan menurut Surah Al-Baqarah (2) : 177 dinyatakan bahwa kebajikan itu adalah beriman kepada Allah, hari kemudian, malaikat-malaikat, kitab-kitab, nabi-nabi dan memberikan harta yang dicintaina kepada kerabatnya, anak-anak yatim orang-orang miskin, musafir yang memerlukan pertolongan dan orang-orang yang meminta-minta, dan memerdekan hamba sahaya, mendirikan shalat dan menunaikan zakat: dan orang-orang yang menepati janjinya apabila ia berjanji, dan orang-orang yang sabat dalam kesempitan, penderitaan dalam peperangan. ${ }^{12}$

Pemaknaan terhadap kebijaksanaan dari penjelasan tersebut disimpulkan bahwa makna bijaksana adalah manusia memahami keluhuran dirinya sebagai pengemban hak dan kewajiban didunia yang patuh pada atas perintah Allah swt agar menjadi bijaksana. Pertanyaan kemudian darimana filsafat mencari dan memperoleh kebijaksanaan. Hal ini bermula dari keingintahuan tentang sesuatu. Seseatu itu bisa berupa hal konkret: meja, kursi, teman, alat-alat kedokteran, buku dan lain sebagainya. Bagi manusia apa yang Nampak dan diketahuinya nanti akan menjadi sebuah pengetahuan. Untuk mendapatkan pengetahuan itu, maka pengenalan akan pengalaman indrawi sangat menentukan. Seseorang dapat membuktikan secara indrawi secara konkret secara faktual. Dengan pembuktian secara indrawi: karena sentuhan, penglihatan, pendengaran, penciuman, daya pengecap, dan argument-argumen yang menguatkannya, maka sebenarnya telah muncul suatu kebenaran tentang pengetahuan itu. ${ }^{13}$

Pengetahuan menurut Al-Kindi dibagi ke dalam pengetahuan illahi dan manusiawi. Pengetahuan ilahi merupakan pengetahuan yang bersumber langsung dari Allah SWT yang biasanya ditunjukkan kepada nabi. Jadi, pengetahuan model ini memegang keyakinan atau iman sebagai prinsipnya. Model pengetahuan kedua dimaknai sebagai pengetahuan manusiawi atau falsafati, di mana rasionalias menjadi tolak ukurnya. Dengan kemampuan yang dimiliki manusia ini berupa

\footnotetext{
${ }^{10}$ Peter Mahmud Marzuki, "Penelitian Hukum” (Kencana, 2019).

${ }^{11}$ Marzuki.

${ }^{12}$ Muhamad Rakhmat, Pengantar Filsafat Hukum (Bandung: CV. Warta Bagja, 2017).

${ }^{13}$ Rakhmat.
} 
pengetahuan yang diperoleh melalui indera manusia, disebut pengetahuan indra (pengetahuan biasa). Jika pengetahuan tersebut diperoleh mengikuti metode dan sistem tertentu serta bersifat universal, disebutlah pengetahuan itu sebgai pengetahuan ilmiah (ilmu). Selanjutnya, apabila pengetahuan itu diperoleh melalui yang sedalam-dalamnya (kontemplasi) sampai kepada hakikatnya, muncullah pengetahuan filsafat. Jika pengetahuan itu bersumber dari keyakinan terhadap ajaran suatu agama, pengetahuan semacam ini disebut pengetahuan agama. ${ }^{14}$

Berangkat pada pengertian filsafat di atas, kemudian muncul pertanyaan apakah filsafat memiliki metode. Menurut Mohammad Noor Syam, metode yang dapat ditempuh dalam memaparkan filsafat, yakni: $:^{15}$

1. Melalui proses Kontemplatif

Perenungan dalam epistemologi modern digambarkan sebagai pengetahuan dari suatu objek, yang berlawanan dengan menikmati, melainkan sebagai kesadaran jiwa kearah kesadaran diri sendiri. Merenung adalah suatu cara yang sesuai dengan dengan watak filsafat, yaitu memikirkan susuatu sedalam-dalamnya. Tentunya proses perenungan yang dilakukan tidaklah dalam waktu sesaat, akan tetapi membutuhkan waktu yang lama dengan dukungan lingkungan yang tenang. Merenung disini bukanlah melamun, juga berpikir secara kebetulan yang bersifat untung-untungan. Perenungan kefilsafatan ialah percobaan tidak hanya untuk menyusun sistem pengetahuan yang rasaional saja, karena objek dari filsafat adalah kehidupan manusia di alam semesta termasuk yang tidak rasional.

2. Melalui proses spekulatif.

Spekulatif dalam konteks filsafat pada hakikatnya memiliki arti yang sama dan atau hamper sama dengan kontemplatif. Olehkarena itu, perenungan yang dilakukan diharapkan dapat bermuara tidak hanya pada objek yang tak terbatas, melainkan juga tujuan yang hendak dicapai yakni mengerti hakikat sesuatu. Mengerti hakikat sesuatu, berarti menyelami sesuatu secara mendalam yang dapat dicapai dengan pikiran yang tenang, kritis dan pikiran murni.

3. Melalui proses deduktif

Berpikir dan penyeleidikan ilmiah umumnya menggunakan metode induktif. Sedangkan filsafat berdasarkan objek dan ruang lingkup menggunakan metode deduktif. Dalam hal ini proses penemuan filsafati dimulai dengan memahami realitas yang bersifat umum, guna mendapatkan kesimpulan-kesimpulan tertentu yang khusus.

Bahwa dengan tahapan proses metode dalam filsafat maka dapat diletakkan pada bentuknya bahwasanya filsafat memiliki metode yang dapat mengkaji secara filosofis makna sebuah ilmu. Pada penggunaan metode didalam filsafat ada tiga cabang utama didalam filsafat yakni Ontologi, Epistemologi dan Aksiologi yang penulis gambarkan dalam bagan seperti yang ditunjukkan pada Gambar 1.

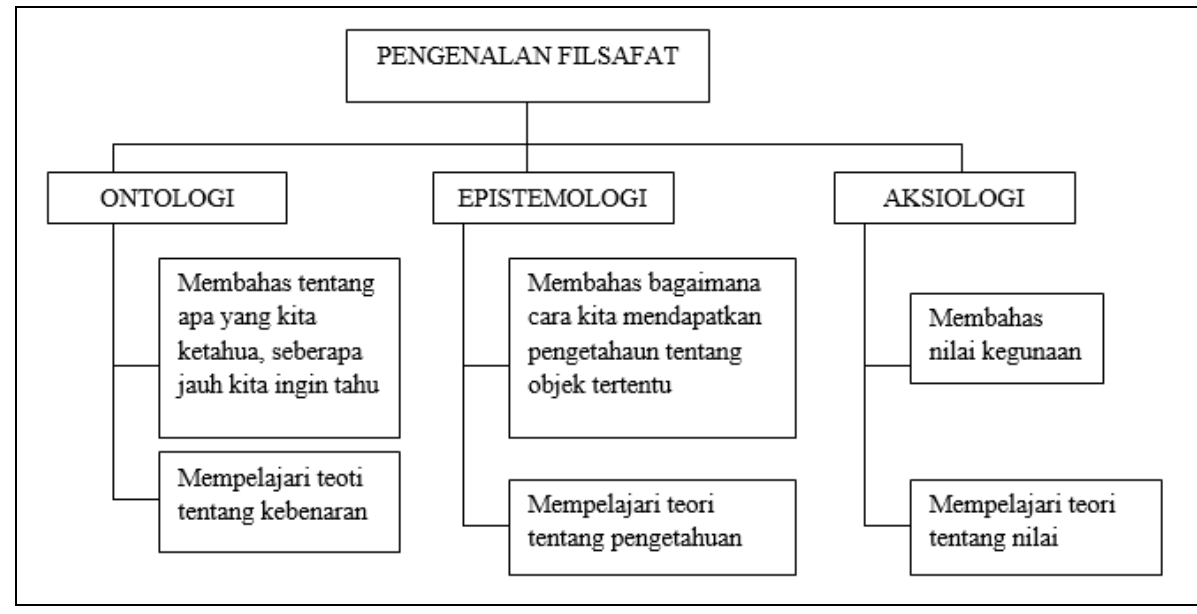

Gambar 1. Memunculkan Style dalam Template

14 Rakhmat.

${ }^{15}$ Sukarno Aburaera and Maskun Muhadar, Filsafat Hukum Teori Dan Praktik, Kencana (Jakarta, 2013). 
Berdasarkan Gambar 1 dapat dimaknai bahwasanya Ontologi mempersoalkan segala sesuatu yang ada. Gambarannya terlihat dari pertanyaan berikut: "apakah manusia itu? apa yang dikatakan adil? apa ada adil itu?. ini semua yang hidup dengan kesadaran, tetapi tidak mudah dijawab. Kalau dihubungkan dengan ilmu, apa yang merupakan ada atau "being" dari ilmu itu. Umpamanya yang merupakan ada pada ilmu hukum yaitu norma (patokan). ${ }^{16}$

Pada ilmu ekonomi adalah benda-benda kebutuhan manusia. Epistemologi, secara garis besar membahas segenap proses dalam usaha memperoleh kebenaran pengetahuan. Cuplikan yang tampil dalam upaya epistemologi memperoleh kebenaran dengan pembahasannya terhadap asal, syarat, susunan, metode, dan validitas pengetahuan. Secara umum terbagi atas empat jenis kebenaran, yaitu kebenaran religius, kebenaran filosofis, kebenaran estetis dan kebenaran ilmiah. Yang termasuk dalam epistomologi, antara lain logika, metodologi dan filsafat ilmu. Kemudian cabang utama ketiga dari pohon filsafat adalah aksiologi. Aksiologi merupakan cabang filsafat yang mempersoalkan tentang nilai. Persoalan tentang nilai tersebut ada pada hakikat nilai itu sendiri, kriterianya dan keberadaan nilai. Nilai dapat diartikan sebagai sifat yang melekat. Sifat yang melekat ini berkaitan dengan persoalan baik atau jahat dan indah atau buruk. Baik atau jahat merupakan persoalan perbuatan manusia, sementara indah atau buruk merupakan persoalan seni. ${ }^{17}$

Penjelasan diatas dapat dipaparkan bahwasanya dalam menelaah sebuah ilmu dalam perspektif filsafat khususnya filsafat ilmu maka ada metode dan cabang utama filsafat yakni Ontologi, Epistemologi dan Aksiologi dalam melakukan kajian terhadap ilmu tersebut. Pada konteks ilmu hukum, Hukum memiliki hubungan timbal balik dengan masyarakatnya, karena hukum itu sendiri merupakan sarana pengatur masyarakat dan bekerja di dalam masyarakat. Itulah sebabnya, hukum tidak terlepas dari gagasan-gagasan maupun pendapat-pendapat yang hidup di kalangan anggota masyarakat. Struktur masyarakat dapat menjadi penghambat sekaligus dapat memberikan saranasarana sosial, sehingga memungkinkan hukum dapat diterapkan sebaikbaiknya. Di lain pihak, suatu sistem hukum tidak bisa berjalan sendirian. Proses saling mempengaruhi antara sistem hukum dengan sistem yang lain yang berada dalam kehidupan masyarakat terus berjalan secara berkelanjutan. Di satu sisi nampak seiring, namun di sisi yang lain, proses ini bisa jadi menggilas sistem yang lain. Yang patut dijadikan rujukan dan mendapat perhatian adalah mengenai adanya budaya yang mengitari kehidupan masyarakat. ${ }^{18}$

Pada hal yang lain secara teoritik dan praktik Ilmu hukum mempunyai karateristik sebagai ilmu yang bersifat perskriptif dan terapan. Sebagai ilmu yang bersifat perskriptif, ilmu hukum mempelajari tujuan hukum, nilai-nilai keadilan, validitas aturan hukum, konsep-konsep hukum dan normanorma hukum. Sebagai ilmu terapan ilmu hukum menetapkan standar prosedur, ketentuan-ketentuan, ramburambu dalam melaksanakan aturan hukum. Sifat perskriptif keilmuan hukum ini merupakan sesuatu yang substansial di dalam ilmu hukum. Hal ini tidak akan mungkin dapat dipelajari oleh disiplin lain yang objeknya juga hukum.

Suatu langkah awal dari substansi ilmu hukum ini adalah perbincangan mengenai makna hukum di dalam hidup bermasyarakat. Dalam hal ini Untuk mempelajari konsep-konsep hukum berarti mempelajari hal-hal yang semula ada dalam alam pikiran yang dihadirkan menjadi sesuatu yang nyata. Konsep hukum, bentukkan hukum ataupun konstruksi hukum merupakan hal-hal yang sangat dibutuhkan di dalam kehidupan bermasyarakat. Adanya konsep hak milik, misalnya merupakan sesuatu yang sangat esensial dalam hidup bermasyarakat. Konsep demikian tidak terjadi secara tibatiba, melainkan mengalami proses berpikir yang panjang. Dengan diketemukannya konsep-konsep semacam itu, mau tidak mau akan diikuti oleh aturan-aturan yang menyertainya.

Mempelajari norma-norma hukum merupakan esensial di dalam ilmu hukum. Belajar ilmu hukum tanpa mempelajari norma-norma hukum sama halnya dengan belajar ilmu kedokteran tanpa mempelajari tubuh manusia. Oleh karena itu ilmu hukum merupakan ilmu normatif, hal ini tidak dapat disangkal dan memang demikian kenyataannya. Dengan demikian tidak ada alasan bagi seorang sarjana hukum akan tetap menganggap ilmu hukum adalah merupakan ilmu yang normatif. Sifat ilmu

${ }^{16}$ Rakhmat, Pengantar Filsafat Hukum.

${ }^{17}$ Rakhmat.

${ }^{18}$ Sobirin Malian, "Perkembangan Filsafat Ilmu Serta Kaitannya Dengan Teori Hukum,” Jurnal Fakultas Hukum UII 33, no. 73 (2010). 
hukum sebagai ilmu terapan merupakan konsekuensi dari sifat perskriptifnya. Suatu penerapan yang salah akan berpengaruh terhadap sesuatu yang bersifat substansial. Suatu tujuan yang benar tetapi dalam pelaksanaannya tidak sesuai dengan apa yang hendak dicapai akan berakibat tidak ada artinya. Mengingat hal tersebut dalam menetapkan standar prosedur atau cara harus berpengang kepada sesuatu yang substansial. Dalam hal inilah ilmu hukum akan menelaah kemungkinan-kemungkinan dalam menetapkan standar tersebut. Berdasarkan sifat keilmuan ilmu hukum dapat dibagi menjadi tiga lapisan, dalam bukunya Jan Gijssels dan Mark van Hoecke membagi ketiga lapisan tersebut adalah rechtsdogmatiek (Dogma Hukum), rechtsteorie (Teori Hukum) dan rechtsfilosie (Filsafat Hukum)

Dalam hal kemurnian ilmu hukum sebagai suatu ilmu, dari ketiga pembagian tersebut dapat dilihat bahwa dua diantaranya (dogma hukum dan teori hukum) adalah merupakan ilmu hukum yang murni dan belum terintegrasi dengan ilmu-ilmu lain sedangkan filsafat hukum telah terintegrasi dengan ilmu-ilmu lain karena didalamnya akan mempelajari banyak hal yang bersilangan dengan ilmuilmu lain. Oleh karena itu ilmu hukum mempunyai dua aspek, yaitu aspek praktis dan aspek teoritis.

Ilmu hukum yang dalam penjabaran manfaatnya memiliki aspek praktis dan aspek teoritis sangat menggugah paradigma filsafat yang menilai ilmu hukum dapat ditelaah berdasarkan metode dan tahapan akar pohon filsafat yaitu secara Ontologi, Epistemologi dan Aksiologi. Eksistensi Ilmu hukum sebagai ilmu dapati ditinjau dari aspek 3 (tiga) landasan pengembangan yakni:

Ontologi

Jika menilik sejarahnya, kata ontologi berasal dari perkataan Yunani: On = Being, dan Logos = Logic. Jadi Ontologi adalah the theory of being qua being (teori tentang keberadaan sebagai keberadaan). (Fajlurrahman Jurdi, 2019, P.78), sedangkan dari segi bahasa, Ontologi berasal dari bahasa Yunani, yaitu On/Ontos = ada, dan Logos = Jadi, ontologi adalah ilmu tentang yang ada. ${ }^{19}$

Menurut istilah, ontologi ialah ilmu yang membahas tentang hakikat yang ada, yang merupakan ultimate reality, baik yang berbentuk jasmani/konkret, maupun rohani/abstrak. Pada pengertian ontology dimaknai bahwa ontologi adalah hakikat yang Ada (being, sein) yang merupakan asumsi dasar bagi apa yang disebut sebagai kenyataan dan kebenaran. dalam perspektif ilmu, ontologi ilmu dapat dimaknai sebagai teori tentang wujud dalam perspektif objek materil ke-Ilmuan, konsepkonsep penting yang diasumsikan oleh ilmu ditelaah secara kritis dalam ontologi ilmu. ${ }^{20}$

Dari definisi dapat dikemukakan bahwasanya dari aspek ontologi, obyek kajian dalam ilmu hukum adalah norma-norma, seperti, norma perilaku dan norma kewenangan, termasuk norma-norma yang telah hidup secara turun temurun dalam masyarakat. Dalam hubungannya antara subyek dengan obyek, posisi subyek berada di luar obyek sebagai pemerhati (touschowuwer). ${ }^{21}$ Sedangkan menurut Bernard Arief Sidharta mengatakan dalam mengembangkan ilmu hukum dalam ranah ontologi ilmu hukum, maka obyek ilmu hukum adalah hukum positif yang berlaku di sebuah Negara tetentu dan waktu tertentu yakni sistem konseptual ass-asas hukum, kaidah-kaidah hukum yang bagian-bagian pentingnya diposifitifkan oleh pengemban kewenangan (otoritas) hukum dalam negara yang bersangkutan, serta lembaga-lembaga hukum untuk mengaktualisaikan sistem konseptual tersebut dan prosesnya. Pengolahan bahan hukum ini dilakukan dengan selalu mengacu keadilan dan konteks kesejarahan dan kemasyarakatan. ${ }^{22}$

Epistemologi

Epistemologi berasal dari bahasa Yunani yang berarti teori ilmu pengetahuan, merupakan gabungan dua kata Episteme: pengetahuan; dan logos, theory. Epistemologi merupakan cabangilmu filsafat yang menengarai masalah-masalah filosofi hal yang mengitari teori ilmupengetahuan. Sebagai bagian dari filsafat yang meneliti asal-usul, asumsi dasar, sifat-sifat dan bagaimana memperoleh

${ }^{19}$ Malian.

${ }^{20}$ Malian.

${ }^{21}$ Edy Faishal Muttaqin, "Eksistensi Ilmu Hukum Terhadap Ilmu-Ilmu Lain Ditinjau Dari Filsafat Ilmu," Jurnal Ilmu Hukum Riau 1, no. 01 (2010).

${ }^{22}$ Junaidi Abdullah, "Refleksi Dan Relevansi Pemikiran Filsafat Hukum Bagi Pengembangan Ilmu Hukum," YUDISIA: Jurnal Pemikiran Hukum Dan Hukum Islam 6, no. 1 (2016): 181-99. 
pengetahuan menjadi penentu penting dalam menentukan sebuah modelfilsafat. Jadi epistemologi menentukan karakter pengetahuan bahkan menentukan "kebenaran" macam apa yang dianggap patut diterima dan apa yang patut ditolak. ${ }^{23}$

Apabila kumpulan pengetahuan yang benar/episteme/diklasifikasi, disusun sistematisdengan metode yang benar dapat menjadi epistemologi. Aspek epistemologi adalah kebenaran fakta/kenyataan dari sudut pandang mengapa dan bagaimana fakta itu benar yang dapatdiverifikasi atau dibuktikan kembali kebenarannya. Dengan memperhatikan definisi epistemologi bisa dikatakan bahwa tema dan pokok pengkajian epistemologi ialah ilmu, makrifat dan pengetahuan. Epistemologi adalah suatu cabang dari filsafat yang mengkaji dan membahas tentang batasan, dasar, dan pondasi, alat, tolok ukur, keabsahan, validitas dan kebenaran ilmu, makrifat, dan pengetahuan manusia. Menurut Harun Nasution, episteme berarti pengetahuan dan epistemology adalah ilmu membahas tentang apa pengetahuan dan bagaimana memperoleh pengetahuan. ${ }^{24}$

Berdasarkan pengertian tersebut nampak bahwa epistemology bersangkutan dengan masalahmasalah yang meliputi: Filsafat yaitu sebagai ilmu berusaha mencari hakekat dan kebenaran pengetahuan; Metode yaitu sebagai metode bertujuan mengantarkan manusia untuk memperoleh realitas kebenaran pengetahuan; dan Sistem yaitu sebagai suatu sistem bertujuan untuk memperoleh realitas kebenaran pengetahuan.

Pandangan epistemologi tentang ilmu hukum bisa merujuk pendapat Philipus M. Hadjon, yang mengemukakan bahwa ilmu hukum memiliki karakter yang khas, yaitu sifatnya yang normatif, praktis, dan preskriptif. Sebagai ilmu yang bersifat preskriptif mempelajari tujuan hukum, nilai-nilai keadilan, validitas aturan hukum, konsep-konsep hukum dan norma-norma hukum. Menurut Mariachiara Tallacchini, dari sisi epistemologi mengatakan bahwa:

The interactions among scientific and normative elements may inform several models, where different nuances exist in how science and the law merge together: scientific knowledge may prevail on legal and political evaluations, or scientific validity may be subordinated to the axiological and normative statements. ${ }^{25}$

Dari sisi epistemologi bahwasanya Interaksi antara elemen ilmiah dan normatif dapat menginformasikan beberapa model, di mana nuansa yang berbeda ada dalam bagaimana ilmu pengetahuan dan hukum bergabung bersama: pengetahuan ilmiah dapat berlaku pada evaluasi hukum dan politik, atau dan validitas ilmiah dapat tunduk pada akologi dan pernyataan normatif. Sebagai ilmu terapan ilmu hukum menetapkan standar prosedur, rambu-rambu dalam menetapkan aturan. Ilmu ukum dibagi menjadi tiga lapisan yaitu dogmatik hukum, teori hukum dan filafat hukum. Ilmu hukum dalam kenyataannya juga mempunyai dua aspek yaitu aspek praktis dan teoretis. Ilmu ukum dalam aspek praktis digunakan untuk memecahkan masalah hukum. ${ }^{26}$ Dalam tataran teoretis ilmu hukum digunakan untuk pengembangan ilmu melalui penelitian normatif dengan ndekatan undang-undang, pendekatan kasus, pendekatan komparatif dan pendekatan konseptual. ${ }^{27}$

Secara umum Metodologi yang dipergunakan dalam ilmu hukum adalah secara induksi dan deduksi, dengan criteria kebenaran secara preskriptif atau seyogianya. Dalam pengembanannya, ilmu hukum menghimpun, menginterpretasi, memaparkan dan mensistematisasi bahan hukum yang terdiri aas asas-asas, aturan-aturan dan putusan-putusan hukum suatu tatatanan hukum untuk menghadirkannya sebagai suatu sistem, sehingga keseluruhannya mewujudkan satu kesatuan yang koheren dengan mengacu pengembanan hukum praktis dan penyelesaian masalah hukum. ${ }^{28}$

Aksiologi

\footnotetext{
${ }^{23}$ Supriyanta Supriyanta, "Hukum Dan Ilmu Hukum Dalam Perspektif Filsafat Ilmu," Jurnal Wacana Hukum 10, no. 2 (2011).

${ }^{24}$ Azzimar Shidqy Pramushinta and Sri Endah Wahyuningsih, "Mengenal Epistemologi Islam Dalam Perkembangan Ilmu Hukum,” Jurnal Hukum Khaira Ummah 12, no. 2 (2017): 197-202.

${ }^{25}$ Mariachiara Tallacchini, "Before and beyond the Precautionary Principle: Epistemology of Uncertainty in Science and Law," Toxicology and Applied Pharmacology 207, no. 2 (2005): 645-51.

${ }^{26}$ Abdullah, "Refleksi Dan Relevansi Pemikiran Filsafat Hukum Bagi Pengembangan Ilmu Hukum."

${ }^{27}$ Marzuki, "Penelitian Hukum."

${ }^{28}$ Muttaqin, "Eksistensi Ilmu Hukum Terhadap Ilmu-Ilmu Lain Ditinjau Dari Filsafat Ilmu."
} 
Aksiologi adalah ilmu yang mengkaji tentang nilai-nilai. Disebut teori tentang nilai sebagai filsafat yang membahas apa kegunaan ilmu pengetahuan manusia. Aksiologi menjawab, untuk apa pengetahuan itu dipergunakan? Bagaimana kaitan antara cara penggunaan tersebut dengan kaidahkaidah moral? Bagaimana penentuan obyek yang ditelaah berdasarkan pilihan-pilihan moral? Bagaimana kaitan antara teknik prosedural yang merupakan operasionalisasi metode ilmiah dengan norma-norma moral. ${ }^{29}$ Oleh karena itu, dari aspek aksiologi ilmu hukum dalam pengembangannya memiliki manfaat berupa penyelesaian terhadap semua masalah hukum konkret (problem solving) yang terjadi dalam masyarakat. Pengembangan ilmu hukum bertujuan untuk menciptakan menjaga dan mengendalikan keamanan, ketertiban, keadilan dan kesejahteraan manusia. Sedangkan relevansi ilmu hukum dengan nilai adalah hukum merupakan nilai, sehingga ilmu hukum kemudian merumuskan dan menerapkan nilai-nilai tersebut.

Berdasarkan paparan diatas, dapat disimpulkan ilmu hukum merupakan ilmu yang dikategorikan sebagai kelompok ilmu praktis, tetapi seperti halnya ilmu kedokteran, ilmu hukum menempati kedudukan istemewa dalam klasifikasi ilmu, bukan hanya karena memiliki sejarah yang panjang, memapankannya dibandingkan dengan ilmu-ilmu lainnya, tetapi juga karena sifatnya sebagai ilmu normatif dan dampak langsungnya terhadap kehidupan manusia dan masyarakat yang terbawa oleh sifat dan problematikanya (masalah mendesak yang inheren dalam kehidupan sehari-hari manusia) yang telah memunculkan dan membimbing pengembangan serta pengembangannya. Dari sudut filsafat ilmu, ilmu hukum dapat diklasifikasikan sebagai ilmu yang memiliki karakter keilmuan sendiri, karena sifatnya yang normatiif. (sui generis), sehingga sulit untuk dikategorikan ke dalam ilmu-ilmu sosial atau humaniora. Pendekatan filsafat ilmu yaitu aspek ontologi, epistemologi dan aksiologi memberikan penegasan bahwasanya bahwa ilmu hukum adalah sebuah ilmu.

\section{B. Hakekat dari Tujuan Pembentukan Ilmu Hukum Sebagai Ilmu}

Keberadaan sebuah ilmu dihubungkan dengan tujuan dalam kerangka ilmu pengetahuan adalah dalma rangka mencari dan memperoleh kebenaran. Tentang kebenaran ini, Plato pernah berkata: "Apakah kebenaran itu? lalu pada waktu yang tak bersamaan, bahkan jauh belakangan Bradley menjawab; "Kebenaran itu adalah kenyataan", tetapi bukanlah kenyataan (das sollen) itu tidak selalu yang seharusnya (das sein) yang terjadi. Dikenal ada beberapa teori dalam menentukan kriteria kebenaran.

Pertama, teori korespondensi adalah paling diterima secara luas oleh kelompok realis. Menurut teori ini, kebenaran adalah kesetiaan kepada realita obyektif (fidelity to objective reality). Kebenaran adalah persesuaian antara pernyataan tentang fakta dan fakta itu sendiri, atau antara pertimbangan (judgement) dan situasi dimana pertimbangan itu berusaha untuk melukiskan, karena kebenaran mempunyai hubungan erat dengan pernyataan atau pemberitaan yang kita lakukan tentang sesuatu. ${ }^{30}$

Secara sederhana dapat disimpulkan bahwa berdasarkan teori korespondensi suatu pernyataan adalah benar jika materi hukum yang dikandung pernyataan itu berkorespondensi (berhubungan) dengan obyek yang dituju atau diatur oleh hukum tersebut. Misalnya "jika seorang melakukan pencurian maka orang tersebut akan dihukum, agar menimbulkan efek jera sehingga orang lain tidak melakukan pencurian lagi dan kehidupan menjadi tertib".

Materi hukum itu adalah benar, sebab sebagaimana kita ketahui bahwa hukum ada dan berfungsi untuk mengatur tingkah laku manusia, agar tidak saling menghacurkan sebagaimana dikemukakan Thomas Hobbes: homo homini lupus (manusia adalah serigala bagi yang lain). Sehingga dengan adanya hukum tercipta suatu ketertiban dan kedamaian yang menuju pada kesejahteraan manusia itu sendiri.

Sekiranya ada orang lain yang mengatakan bahwa "pencuri itu tidak dapat dihukum, meskipun telah terbukti" maka tentu saja, pernyataan itu adalah tidak benar. Sebab di dalam hukum diatur mengenai apa yang boleh dilakukan dan apa yang tidak boleh dilakukan. Pencurian merupakan perbuatan yang tidak boleh dilakukan atau dilarang oleh hukum. Oleh sebab itu, seorang pencuri yang telah terbukti melakukan pencurian harus dihukum agar timbul efek jera dan menciptakan ketertiban di

\footnotetext{
${ }^{29}$ Supriyanta, "Hukum Dan Ilmu Hukum Dalam Perspektif Filsafat Ilmu."

${ }^{30}$ Beniharmoni Harefa, "KEBENARAN HUKUM PERSPEKTIF FILSAFAT HUKUM," Jurnal Komunikasi Hukum (JKH) 2, no. 1 (2016).
} 
dalam kehidupan masyarakat. Dalam hal ini maka secara faktual "setiap orang yang bersalah dapat dihukum, dengan berdasarkan pembuktian, guna menciptakan kedamaian dan ketertiban di dalam kehidupan manusia".

Menurut teori koresponden, ada atau tidaknya keyakinan tidak mempunyai hubungan langsung terhadap kebenaran atau kekeliruan. Kekeliruan itu tergantung kepada kondisi yang sudah ditetapkan atau diingkari. Jika sesuatu pertimbangan sesuai dengan fakta, maka pertimbangan ini benar, jika tidak, maka pertimbangan itu salah. Dalam wilayah kebenaran hukum berdasarkan teori korespondensi, kesesuaian putusan hakim dengan kebenaran fakta-fakta hukum sangat diutamakan. Kebenaran legalitas, artinya penerapan hukum hukum terhadap sebuah perkara didasarkan pada faktafakta hukum yang terdapat pada peristiwa yang terjadi. Teori kebenaran korespondensi mengutamakan kepastian hukum (asas legalitas). ${ }^{31}$

Teori yang kedua tentang kebenaran adalah teori koherensi. Berdasarkan teori ini suatu pernyataan dianggap benar bila pernyataan itu bersifat koheren atau konsisten dengan pernyataanpernyataan sebelumnya yang dianggap benar, artinya pertimbangan adalah benar jika pertimbangan itu bersifat konsisten dengan pertimbangan lain yang telah diterima kebenarannya, yaitu yang koheren menurut logika. Misalnya, bila kita menganggap bahwa "semua manusia pasti akan mati" adalah suatu pernyataan yang benar, maka pernyataan bahwa "si Budi adalah seorang manusia dan si Budi pasti akan mati" adalah benar pula, sebab pernyataan kedua adalah konsisten dengan pernyataan yang pertama. Kelompok idealis, seperti Plato juga filsuf-filsuf modern seperti Hegel, Bradley dan Royce memperluas prinsip koherensi ini dengan begitu maka tiap-tiap pertimbangan yang benar dan tiap-tiap sistem kebenaran yang parsial bersifat terus menerus dengan keseluruhan realitas dan memperolah arti dari keseluruhan tersebut. Meskipun demikian perlu lebih dinyatakan dengan referensi kepada konsistensi faktual, yakni persetujuan antara suatu perkembangan dan suatu situasi lingkungan tertentu terhadap teori kebenaran ini.

Dikaitkan dengan kebenaran hukum, teori koherensi diimplementasikan dalam tataran ius constituendum, (ide-ide hukum) yang kesesuaian dengan realitas perilaku masyarakat. Kebenaran hukum yang hendak dipenuhi dalam hal ini adalah aspek keadilan yang diutamakan. Rasa keadilan untuk setiap orang atau kelompok sangat variatif, oleh sebab itu menggunakan teori ini secara mutlak untuk mengungkapkan kebenaran hukum, rasanya tidak mungkin. Karena apa yang dirasakan adil, belum tentu sesuai dengan kepastian dan kemanfaatan hukum. Teori yang ketiga, yakni teori pragmatik. Dicetuskan oleh Charles S. Peirce dalam sebuah makalah berjudul "How to Make Ideals Clear". Teori ini kemudian dikembangkan oleh beberapa ahli filsafat yang kebanyakan adalah berkebangsaan Amerika yang menyebabkan filsafat ini sering dikaitkan dengan filsafat Amerika. Ahliahli filsafat ini di antaranya adalah William James, John Dewey, George Hobart Mead, dan C.I. Lewis. Pragmatisme menantang segala otoritanianisme, intelektualisme dan rasionalisme. Bagi mereka yang menganut pragmatisme, ujian terhadap kebenaran adalah manfaat (utility), kemungkinan dikerjakan (workability) atau akibat yang memuaskan. Sehingga dapat dikatakan bahwa pragmatism adalah suatu aliran yang mengajarkan bahwa yang benar ialah apa yang membuktikan dirinya sebagai benar dengan perantaraan akibat-akibatnya yang bermanfaat secara praktis. Pegangan pragmatis adalah logika pengamatan dimana kebenaran itu membawa manfaat bagi hidup praktis dalam kehidupan manusia.

Dikaitkan dengan kebenaran hukum, menggunakan teori pragmatis maka kebenaran hukum berhubungan dengan kemanfaatan hukum. Oleh karena itu, dalam perspektif kebenaran pragmatis tidak berorientasi pada sebuah proses atau suatu peristiwa hukum tetapi hasil dari proses atau peristiwa hukum itu. Sesuatu dikatakan benar apabila mempunyai manfaat bagi kehidupan umat manusia. Apa yang dirasakan bermanfaat itulah hukum yang sebenarnya. Lagi-lagi ini tidak bisa digunakan secara mutlak dalam mencari dan mengungkapkan kebenaran hukum. fungsi hukum itu sendiri, maka dapat disimpulkan. ${ }^{32}$

Pertama, apakah benar hukum itu merupakan sekumpulan peraturan-peraturan atau kaedahkaedah dalam suatu kehidupan bersama, maka benar hukum merupakan kumpulan aturan. Kedua, apakah benar fungsi hukum itu adalah untuk mengatur kehidupan manusia maka jawabannya

${ }^{31}$ Harefa.

${ }^{32}$ Harefa. 
benar. Kendati memang harus ditegaskan bahwa hukum itu ada untuk manusia bukan manusia ada untuk hukum.

Keberadaan teori tentang kebenaran dalam ilmu hukum semakin mempertegas bahwasanya keberadaan ilmu hukum sebagai ilmu memiliki tujuan tersendiri yakni ditinjau dari aspek kebenaran pragmatis bahwasanya keberadaan hukum untuk memanusiakan manusia (aspek manfaatnya) maka apa yang diatur didalam peraturan-peraturan hukum harus membawa manfaat terhadap kehidupan manusia. Manfaat yang dimaksudkan adalah keberadaan hukum harus membawa kedamaian didalam masyarakat. Sebagimana yang dikemukan oleh Achmad ali bahwasanya tujuan dari hukum bahwa bukan kepastian hukum, bukan kemanfaatan hukum dan bukan keadilan namun yang menjadi tujuan hukum melainkan keadamaian (peace). ${ }^{33}$

Oleh Achmad ali dijelaskan bahwa dalam rangka mencapai tujuan dari pembentukan ilmu hukum sebagai ilmu yang membawa ilmu maka hukum itu sejatinya memiliki fungsi yakni a) hukum sebagai a tool of social control, b) hukum sebagai a tool of social engineering, c) hukum sebagai simbol, d) hukum sebagai a political instrument dan hukum sebagai integrator. Dengan fungsi yang melekat pada ilmu hukum itu maka dengan sifat tujuan dari pembentukan ilmu hukum sebagai ilmu maka hukum hadir untuk memanusiakn manusia. ${ }^{34}$

Olehkarena itu, dengan penjelasan diatas maka secara umum ada tiga hal yang dapat dipelajari dari hukum, yaitu: $:^{35}$

1. Nilai-nilai hukum, seperti keadilan, ketertiban, kepastian hukum dan lain-lain;

2. Kaidah-kaidah hukum berupa kaidah yang tertulis maupun tidak tertulis, kaidah yang bersifat abstrak maupun nyata;

3. Perilaku hukum atau dapat juga disebut kenyataan hukum atau peristiwa hukum. Secara umum, filsafat hukum mengkaji nilai-nilai hukum, sosiologi hukum, antropologi hukum, psikologi hukum, dan lain-lain serta mengkaji perilaku hukum. Dalam fi lsafat hukum, nilainilai yang dikajipun harus bersifat normatif. Ciri yang umum dari kaidah hukum ialah adanya legitimasi dan sanksi. Ilmu hukum sebagai ilmu bertujuan untuk mencari kebenaran atau tepatnya keadilan yang benar. Untuk mencari keadilan yang benar itu maka ditentukanlah cara untuk mencarinya yang disebut metode. Kebenaran yang dapat dicapai oleh ilmu hukum ialah apabila disadari adanya penampakan dari obyek dan seraya menyadari pula arti dibelakang obyek tersebut. Secara hakekat, ilmu hukum berusaha untuk menampilkan hukum secara integral. Ilmu hukum akan mempunyai kewibawaan dan kekuatannya apabila bersifat integral dalam aspek ontologis, epistemologis dan aksiologis. Sebab itu yang diperlukan dalam ilmu hukum ialah sintesis dari metode-metode, sehingga ilmu hukum memiliki suatu metode yang mempunyai ciri khas. Ilmu hukum adalah suatu sistem. Sebagai suatu sistem, ilmu hukum harus merupakan suatu kebulatan dari seluruh komponen atau subsistem yang satu sama lainnya saling berhubungan. Ilmu hukum bersifat dinamis. Ilmu hukum mempunyai peran dan fungsi yang khas dibanding dengan bidang-bidang hukum yang lain.

Secara aksiologis, peran dan fungsi dari ilmu hukum antara lain seperti diuraikan dibawah ini: ${ }^{36}$

1. Ilmu hukum berpengaruh dalam pembentukan hukum melalui penyusunan perundangundangan;

2. Ilmu hukum berpengaruh dalam praktek hukum atau pelaksanaan hukum;

3. Ilmu hukum berpengaruh dalam pendidikan hukum. Pendidikan hukum yang formal yakni di bangku sekolah dan yang informal di tengah masyarakat lewat media massa dan penyuluhanpenyuluhan sangat dipengaruhi oleh ilmu hukum;

4. Ilmu hukum akan berpengaruh atas perkembangan dari bidang-bidang yang lainnya. Dalam suatu sistem hukum yang berusaha untuk mengatur segala hal atau segala bidang, maka sistem seperti itu bersifat progressif dan interventif;

5. Ilmu hukum berusaha untuk mengadakan sistematisasi. Bahan-bahan yang tercerai berai disatukan dalam suatu susunan yang bersifat komprehensif. Hasil sistematisasi menyajikan informasi yang memudahkan.

${ }^{33}$ Achmad Ali, “Menguak Tabir Hukum,” Bogor: Ghalia Indonesia, 2008.

${ }^{34}$ Ali.

${ }^{35}$ Malian, "Perkembangan Filsafat Ilmu Serta Kaitannya Dengan Teori Hukum."

${ }^{36}$ Malian. 


\section{SIMPULAN}

Paradigma filsafat ilmu terhadap eksistensi ilmu hukum dapat ditinjau dari aspek Ontologi, aspek Epistemologi dan Aksiologi. Pada Aspek Ontologi obyek kajian dalam ilmu hukum adalah norma-norma, seperti, norma perilaku dan norma kewenangan, termasuk norma-norma yang telah hidup secara turun temurun dalam masyarakat, aspek epistemologi adalah ilmu hukum menghimpun, menginterpretasi, memaparkan dan mensistematisasi bahan hukum yang terdiri aas asas-asas, aturanaturan dan putusan-putusan hukum suatu tatatanan hukum untuk menghadirkannya sebagai suatu sistem dan dari aspek Aksiologi ilmu hukum dalam pengembangannya memiliki manfaat berupa penyelesaian terhadap semua masalah hukum konkret (problem solving) yang terjadi dalam masyarakat sedangkan hakekat dari Tujuan Pembentukan Ilmu Hukum Sebagai Ilmu dapat ditelaah dari hakekat dari lahirnya ilmu itu sendiri yakni kehadirannya untuk mencari kebenaran. Kebenaran dalam Ilmu hukum dihubungkan dengan Teori-Teori Kebenaran sejatinya ilmu hukum mencari kebenaran pragmatis yang mana keberadaannya sebagai ilmu untuk membawa manfaat (kedamaian) di tengah-tengah kehidupan masyarakat.

\section{DAFTAR PUSTAKA}

Abdullah, Junaidi. "Refleksi Dan Relevansi Pemikiran Filsafat Hukum Bagi Pengembangan Ilmu Hukum." YUDISIA: Jurnal Pemikiran Hukum Dan Hukum Islam 6, no. 1 (2016): 181-99.

Aburaera, Sukarno, and Maskun Muhadar. Filsafat Hukum Teori Dan Praktik. Kencana. Jakarta, 2013.

Ali, Achmad. "Menguak Tabir Hukum.” Bogor: Ghalia Indonesia, 2008.

Arief Sidharta, B. Apakah Hukum Itu. Bandung: Universitas Katolik Parahyangan, 2000.

Hadisuprapto, Paulus. "Ilmu Hukum (Pendekatan Kajiannya)." Inovatif: Jurnal Ilmu Hukum 2, no. 4 (2010).

Harefa, Beniharmoni. Kebenaran Hukum Perspektif Filsafat Hukum. Jurnal Komunikasi Hukum (JKH) 2, no. 1 (2016).

Judson, H F. "The Difficult Interface: Relations between the Sciences and the Law." PERSPECTIVES ON PROPERTIES OF THE HUMAN GENOME PROJECT 50 (2003): 483-505.

Malian, Sobirin. "Perkembangan Filsafat Ilmu Serta Kaitannya Dengan Teori Hukum." Jurnal Fakultas Hukum UII 33, no. 73 (2010).

Marzuki, Peter Mahmud. "Penelitian Hukum.” Kencana, 2019.

Muttaqin, Edy Faishal. "Eksistensi Ilmu Hukum Terhadap Ilmu-Ilmu Lain Ditinjau Dari Filsafat Ilmu." Jurnal Ilmu Hukum Riau 1, no. 01 (2010).

Pramushinta, Azzimar Shidqy, and Sri Endah Wahyuningsih. "Mengenal Epistemologi Islam Dalam Perkembangan Ilmu Hukum.” Jurnal Hukum Khaira Ummah 12, no. 2 (2017): 197-202.

Rakhmat, Muhamad. Pengantar Filsafat Hukum. Bandung: CV. Warta Bagja, 2017.

Rosyidah, Inayatur. "Relevansi Ilmu Pengetahuan, Filsafat, Logika Dan Bahasa Dalam Membentuk Peradaban." El Harakah 12, no. 1 (2010): 19.

Supriyanta, Supriyanta. "Hukum Dan Ilmu Hukum Dalam Perspektif Filsafat Ilmu." Jurnal Wacana Hukum 10, no. 2 (2011).

Tallacchini, Mariachiara. "Before and beyond the Precautionary Principle: Epistemology of Uncertainty in Science and Law." Toxicology and Applied Pharmacology 207, no. 2 (2005): 645-51. 